\title{
Komposisi Dan Struktur Vegetasi Riparian Di Kawasan Taman Wisata Gunung Poteng Singkawang Kalimantan Barat
}

\author{
Imanuel Tiko Junardi ${ }^{1}$, Rafdinal' ${ }^{1}$, Riza Linda ${ }^{\mathbf{1}}$ \\ ${ }^{1}$ Program Studi Biologi, Fakultas MIPA Universitas Tanjungpura,Jl. Prof. Dr. H. Hadari Nawawi, Pontianak \\ Email : tiko.junardi.93@gmail.com
}

\begin{abstract}
Riparian ecosystem s an area that has ecological potential in supporting river ecosystems. This area is usually overgrown by various types of plants that have adapted to live in a place that is often inundated by river water, especially when it rains. Research on the composition and structure of riparian vegetation in Mount Poteng area was carried out in April - June 2017. The method used in this study was a line method with a combination of paths carried out in 4 locations. The width of each lane is 20 meters and the length is \pm 100 meters. Results of the sample plot of 0.03 ha in riparian forest around the Poteng mountain area found a composition of riparian vegetation consisting of 23 species, 21 genera and 19 families. Araceae family is the family that dominates the Mount Poteng riparian area. Tree stand density ranges from 5-60 individuals / ha with diversity index ranging from 0.6 to 1.5 .
\end{abstract}

Keywords: Riparian, Vegetation, Composition, Structure, Mount Poteng.

\section{PENDAHULUAN}

Vegetasi riparian memiliki peran yang sangat penting dalam menentukan struktur dan fungsi ekosistem sungai. Daerah riparian berfungsi untuk mengurangi erosi tanah, mempertahankan temperature sungai, mengurangi sedimen yang masuk kesungai, memproses nutrien, dan masukan material organik kedalam sungai, serta menjadi tempat perlindungan bagi biota atau organisme lain. Selain fungsi-fungsi yang disebutkan di atas, riparian memiliki nilai lain sebagai bagian dari warisan budaya umat manusia. Keberadaan riparian seringkali terkait dengan keyakinan agama, kosmologi, dan nilai-nilai spiritual yang membentuk dasar tradisi sosial, ekonomi, dan budaya masyarakatnya. Lebih lanjut, riparian juga berfungsi sebagai cagar alam ataupun sumber inspirasi estetika dan artistik (Haslam, 2008).

Lahan basah riparian memiliki sejumlah fungsi sangat penting bagi lingkungan perkotaan sebagai layanan ekosistem (ecosystem service) yang tidak dapat dinilai langsung keekonomiannya. Di samping fungsi layanan ekosistem tersebut, lahan basah juga memiliki beberapa nilai ekonomi seperti penyimpanan air, perlindungan badai, stabilisasi garis sungai, mengendalikan erosi, kawasan sumber dan resapan air tanah, pemurnian air, retensi nutrisi, sedimen, dan polutan, stabilisasi kondisi iklim setempat khususnya curah hujan dan temperature. Beberapa fungsi tersebut memiliki nilai yaitu sebagai tempat pasokan air, perikanan, keberagaman biota liar, penyedia kayu dan bahan bangunan lainnya, sumber daya energi, sumber daya satwa liar, prasarana transportasi penyedia berbagai macam produk dari tanaman dan fauna, potensi bagi kegiatan rekreasi dan pariwisata (Ramsar, 2013).

Gunung Poteng adalah salah satu kawasan yang termasuk dalam hutan Cagar Alam Raya Pasi dengan luas 3.700 ha yang telah ditetapkan sesuai SK Menhut Nomor 111/Kpts-II/1990 pada tanggal 20 Mei 1978 ini memiliki beraneka ragam pesona alam yang indah. Merupakan tempat wisata alam bagi yang menyukai hobi berpetualang menjelajah hutan (BPS Singkawang, 2015). Kawasan ini merupakan tempat tumbuhnya bunga rafflesia tuan mudae, anggrek singkawang (Dendrobium Singkawangense), bunga law belacan (Rhizanthes Zippelii) serta berbagai jenis fauna seperti beruang madu, trenggiling dan landak. Gunung ini menyimpan kekhasan flora seperti Bungai Bangkai (Amorphopallus sp), Bunga Padma Raksasa (Rafflesia Tuan Mudae), Bunga Bintang (Rizhantes Zepelii), dan aneka ragam anggrek yang 
dilindungi. Beruang madu, trenggiling, dan landak adalah fauna penghuni Gunung Poteng (Wawan, 2011).

\section{Waktu dan Tempat}

Penelitian ini dilaksanakan pada Bulan April hingga Juni 2017. Lokasi penelitian terletak di kawasan Gunung Poteng, Kota Singkawang (Gambar 1.) dan Laboratorium Biologi Fakultas Matematika dan Ilmu Pengetahuan Alam Universitas Tanjungpura Pontianak.

\section{BAHAN DAN METODE}

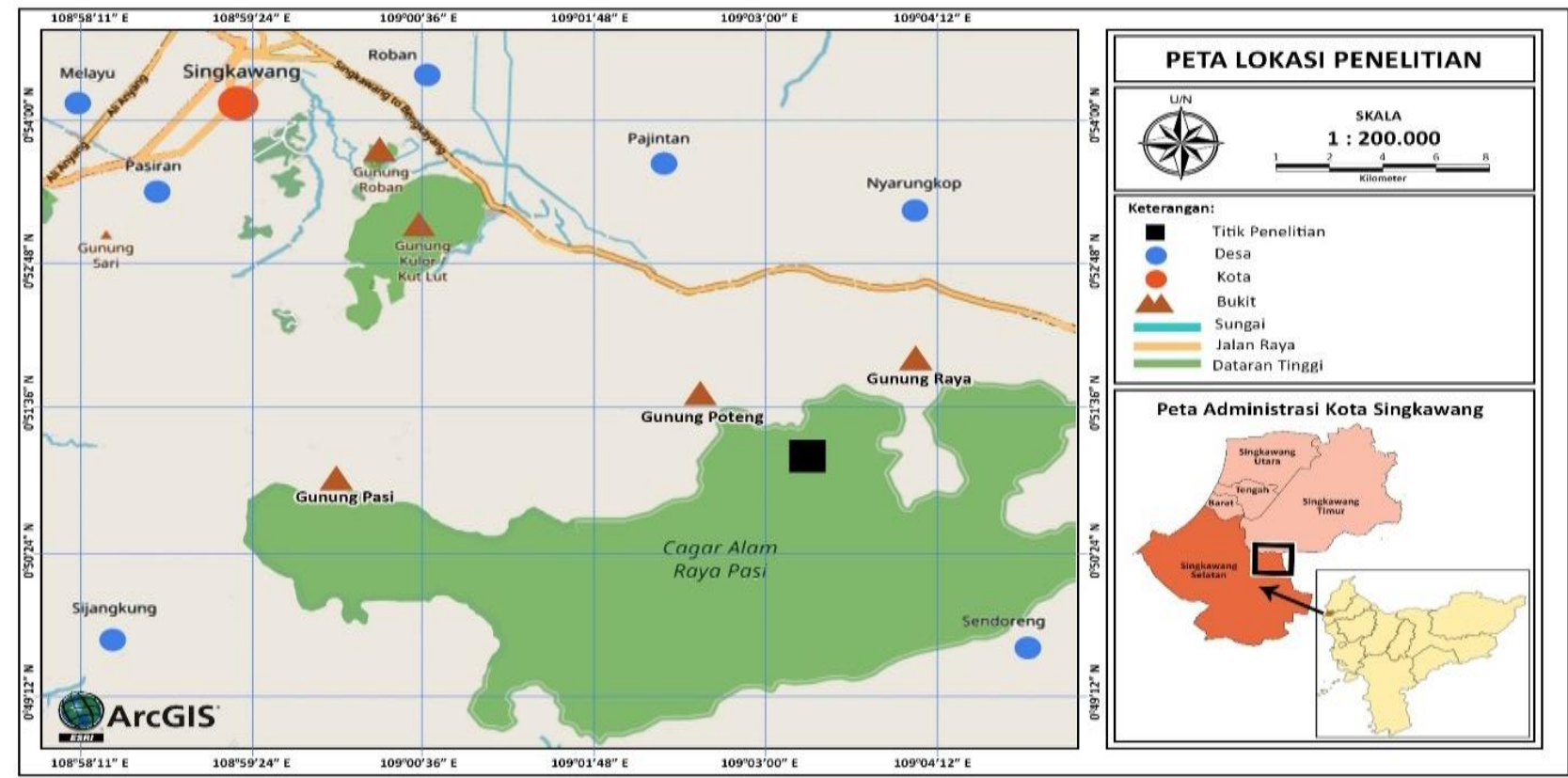

Gambar 1. Lokasi Penelitian di Kawasan Gunung Poteng

Metode yang digunakan dalam penelitian ini adalah metode garis berpetak dengan kombinasi jalur (Seorianegara dan Indrawan, 1988). Petak pengamatan komposisi hutan dibuat jalur lurus memanjang sepanjang aliran sungai di Kawasan Gunung Poteng Kota Singkawang, dengan 4 plot. Lebar tiap jalur 20 meter dan panjang \pm 100 meter (menyesuaikan kondisi lapangan). Adapun tahapan yang dilakukan menurut Kusmana (1997) dalam Indriyanto (2006) dalam analisis vegetasi adalah menempatkan starting point sebagai titik awal bergerak untuk penentuan jalur pengamatan di lapangan. Setiap jalur pengamatan dibuat subplot pengamatan berukuran $2 \mathrm{~m} \times 2 \mathrm{~m}$ untuk tingkat semai, $5 \mathrm{~m} \times 5 \mathrm{~m}$ untuk tingkat pancang, $10 \mathrm{~m} \times 10 \mathrm{~m}$ untuk tingkat tiang dan $20 \mathrm{~m} \times 20 \mathrm{~m}$ untuk tingkat pohon (Gambar 2.).

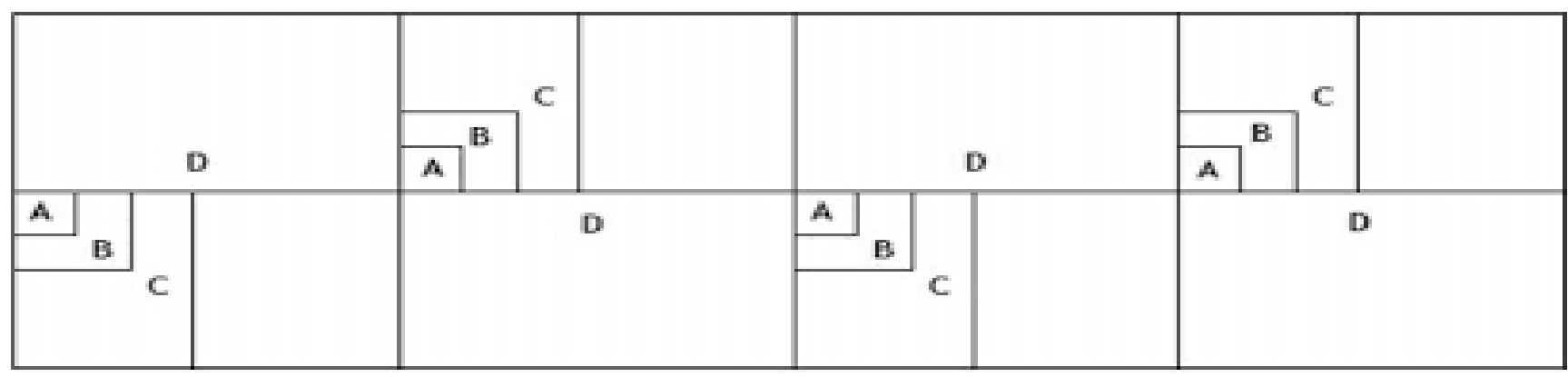

Gambar 2. Desain Metode Garis Petak Kombinasi Jalur (Seorianegara dan Indrawan, 1978) 
Protobiont (2018) Vol. 7 (3) : 118 -126

\section{HASIL DAN PEMBAHASAN}

\section{Hasil}

Berdasarkan hasil penelitian pada petak contoh sebesar 0,03 ha di hutan riparian sekitar kawasan gunung Poteng ditemukan komposisi vegetasi riparian terdiri dari 23 spesies, 21 marga dan 19 famili (Tabel 1.).

Berdasarkan jumlah family vegetasi, famili yang paling mendominasi daerah riparian kawasan gunung Poteng famili Areceae yang terdiri dari 3 jenis vegetasi yaitu: Arenga pinnata, Elaeis guinensis jacq. dan Corypha sp. Kemudian diikuti famili Euphorbiaceae yang terdiri dari 2 jenis vegetasi yaitu: Hevea brasiliensis dan Mallotus paniculatus.
Tabel 1. Jumlah Spesies, Marga dan Family Vegetasi Riparian

\begin{tabular}{ll}
\hline Uraian & Gunung Poteng \\
\hline Ketinggian & $725 \mathrm{mdpl}$ \\
Luas plot & $0,03 \mathrm{ha}$ \\
Jumlah species & 23 \\
Jumlah marga & 22 \\
Jumlah famili & 19 \\
\hline
\end{tabular}

Komposisi vegetasi riparian kawasan gunung Poteng berdasarkan tingkat perkembangan tegakan tergambar pada gambar 3, jumlah jenis vegetasi tertinggi ditemukan pada tingkat semai berjumlah 9 jenis. Tingkat regenerasi tertinggi selanjutnya ditemukan pada tingkat pohon 6 jenis, lalu tingkat pancang terdiri dari 4 jenis tumbuhan.

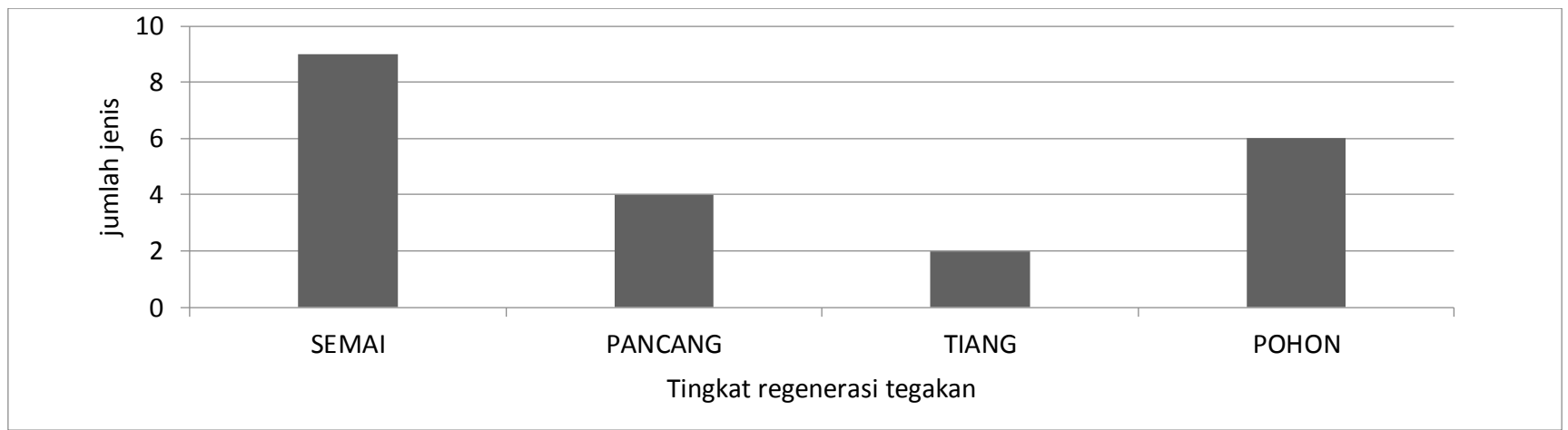

Gambar 3. Jumlah Jenis Vegetasi Riparian Berdasarkan Tingkat Regenerasi Tegakan

Tingkat heterogenitas tegakan dapat dilihat dari frekuensi relatifnya berdasarkan frekuensi relatif tingkat heterogenitas vegetasi tingkat pohon berkisar dari 6,67-33,33\% (Tabel 2.). Frekuensi relatif tertinggi tingkat pohon di temukan pada jenis Hevea brasiliensis $(\mathrm{FR}=33.33 \%)$, berkombinasi dengan Litsea amara (FR $=26,67 \%)$, dan Alstonia sp. ( FR = 20\%). Jenis Mallotus paniculatus, Leucaena leucephala, dan Aquilaria malaccenensis memiliki frekuensi relatif (FR) yang sama sebesar 6,67\%.

Kerapatan tingkat pohon berkisar 5-60 individu/ha, kerapatan pohon tertinggi di temukan pada jenis Hevea brasiliensis dengan kepadatan 60 individu/ha $(\mathrm{KR}=48 \%)$, kemudian dilanjutkan jenis Litsea amara dan Alstonia sp. masing-masing sebesar 30 individu/ha $(\mathrm{KR}=24 \%)$ dan 20 individu/ha $(\mathrm{KR}=$
16\%). Untuk jenis Mallotus paniculatus, Leucaena leucephala, dan Aquilaria malaccenensis memiliki kerapatan 5 individu/ha $(\mathrm{KR}=4 \%)$ dapat dilihat pada tabel 2.

Tingkat dominasi tegakan dapat dilihat dari Indeks Nilai Penting (INP) suatu jenis, berdasarkan nilai INP tingkat heterogenitas vegetasi tingkat pohon pada riparian di kawasan Gunung Poteng berkisar dari 10,67-119\% (Tabel 2.). Nilai INP tertinggi tingkat pohon di temukan pada jenis Hevea brasiliensis INP $=119,00 \%$, berkombinasi dengan Litsea amara $\mathrm{INP}=86,09 \%$, dan Alstonia $\mathrm{sp}$. INP = $62,90 \%$. Jenis Mallotus paniculatus, Leucaena leucephala, dan Aquilaria malaccenensis memiliki INP yang sama, sebesar $10,67 \%$. Hal yang sama di jumpai juga pada tingkat pancang dan tiang. 
Tabel 2. Komposisi Vegetasi Riparian Tingkat Pohon

\begin{tabular}{lllllll}
\hline Jenis & N & K & KR $(\%)$ & F & FR $(\%)$ & INP $(\%)$ \\
\hline Hevea brasiliensis & 12 & 60.00 & 48.00 & 1.00 & 33.33 & 119.00 \\
Alstonia sp. & 4 & 20.00 & 16.00 & 0.60 & 20.00 & 62.90 \\
Litsea amara & 6 & 30.00 & 24.00 & 0.80 & 26.67 & 86.09 \\
Mallotus paniculatus & 1 & 5.00 & 4.00 & 0.20 & 6.67 & 10.67 \\
Leucaena leucephala & 1 & 5.00 & 4.00 & 0.20 & 6.67 & 10.67 \\
Aquilaria malaccenensis & 1 & 5.00 & 4.00 & 0.20 & 6.67 & 10.67 \\
\hline Jumlah & 25 & 125.00 & 100 & 3 & 100 & \\
\hline
\end{tabular}

Keterangan: N: jumlah spesies, K: kerapatan, KR: kerapatan relatif, FR: frekuensi relatif, INP: indeks nilai penting

Kerapatan tingkat tiang berkisar 40-100 individu/ha, kerapatan tiang tertinggi di temukan pada jenis Hevea brasiliensis dengan kepadatan 100 individu/ha $(\mathrm{KR}=71,43 \%)$, dilanjutkan jenis Alstonia sp. masing-masing sebesar individu dan 20 individu/ha $(\mathrm{KR}=28,57 \%)$. Fekuensi relatif tingkat tiang berkisar 40-60\%, tertinggi di temukan pada jenis Hevea brasiliensis dengan FR $=60 \%$ dan Alstonia $\mathrm{sp}$. FR $=40 \%$. Indeks Nilai Penting tingkat tiang berkisar 68,57-131,43\% tertinggi ditemukan pada jenis Hevea brasiliensis dengan nilai INP = 131,43\% dan jenis Alstonia sp. dengan nilai INP = $68,57 \%$ (Tabel 3.)

Tabel 3. Komposisi Vegetasi Tingkat Tiang

\begin{tabular}{lllllll}
\hline Jenis & $\mathbf{N}$ & $\mathbf{K}$ & KR $(\boldsymbol{\%})$ & F & FR $(\%)$ & INP $(\%)$ \\
\hline Hevea brasiliensis & 5 & 100.000 & 71.43 & 0.60 & 60.00 & 131.43 \\
Alstonia sp. & 2 & 40.000 & 28.57 & 0.40 & 40.00 & 68.57 \\
\hline Jumlah & 7 & 140 & 100 & 1 & 100 & \\
\hline
\end{tabular}

Kerapatan tingkat pancang berkisar 80-400 individu/ha, kerapatan tiang tertinggi ditemukan pada jenis Hevea brasiliensis dengan kepadatan 400 individu/ha $(\mathrm{KR}=71,43 \%)$, dilanjutkan jenis Durio zibethinus, Corypha sp., dan Gnetum gnemon masing-masing sebesar 80 individu/ha $(\mathrm{KR}=14,29 \%)$. Fekuensi relatif tingkat pancang berkisar 14,29-71,43\%, tertinggi ditemukan pada jenis Hevea brasiliensis dengan $\mathrm{FR}=71,43 \%$, dilanjutkan jenis Durio zibethinus, Corypha sp., dan Gnetum gnemon masing-masing sebesar 14,29\%. Indeks Nilai Penting tingkat pancang berkisar 28,57$142,86 \%$, tertinggi ditemukan pada jenis Hevea brasiliensis dengan INP $=142,86 \%$, dilanjutkan jenis Durio zibethinus, Corypha sp., dan Gnetum gnemon masing-masing sebesar $28,57 \%$ (Tabel 4.).

Tabel 4. Komposisi Vegetasi Tingkat Pancang

\begin{tabular}{lllllll}
\hline Jenis & N & K & KR $(\%)$ & F & FR (\%) & INP (\%) \\
\hline Hevea brasiliensis & 5 & 400.00 & 71.43 & 1.00 & 71.43 & 142.86 \\
Durio zibethinus & 1 & 80.00 & 14.29 & 0.20 & 14.29 & 28.57 \\
Corypha sp. & 1 & 80.00 & 14.29 & 0.20 & 14.29 & 28.57 \\
Gnetum gnemon & 1 & 80.00 & 14.29 & 0.20 & 14.29 & 28.57 \\
\hline Jumlah & 8 & 560 & 100 & 1.4 & 100 & \\
\hline
\end{tabular}

Kerapatan vegetasi riparian kawasan gunung Poteng tingkat semai tegakan pada tabel 5., kerapatan tingkat semai berkisar 500-8500 individu/ha, kerapatan tingkat semai tertinggi di temukan pada jenis Neprolephis sp. dengan kerapatan 8500 individu/ha $(\mathrm{KR}=53,13 \%)$, jenis Hevea brasiliensis memiliki tingkat kerapatan sebesar 3000 individu/ha $(\mathrm{KR}=18,75 \%)$. Kerapatan tertinggi selanjutnya adalah Cyperus sp. dan Dicranopteris linearis 1000 individu/ha ( $\mathrm{KR}=6,25 \%)$. Untuk jenis Dillenia sp., Nephelium lappaceum, Pandanus tectorius, Elaeis 
guinensis jacq., dan Melastoma candidum memiliki kerapatan 500 individu/ha $(\mathrm{KR}=3,13 \%)$.

Tingkat keanekaragaman jenis vegetasi tegakan dapat dilihat dari frekuensi relatifnya. Berdasarkan frekuensi relatif heterogenitas vegetasi tingkat semai berkisar dari 6,67-33,3\% (Tabel 5.). Frekuensi relatif tertinggi tingkat semai di temukan pada jenis Neprolephis sp.

$(\mathrm{FR}=33.33 \%)$, lalu jenis Hevea brasiliensis $(\mathrm{FR}=$ 20\%). Jenis Cyperus sp., Dicranopteris linearis, Dillenia sp., Nephelium lappaceum, Pandanus tectorius, Elaeis guinensis dan Melastoma candidum, memiliki frekuensi relatif (FR) yang sama sebesar $6,67 \%$.

Tingkat dominasi tegakan dapat dilihat dari Indeks Nilai Penting (INP) suatu jenis, berdasarkan nilai INP tingkat heterogenitas vegetasi tingkat semai pada riparian di kawasan gunung Poteng berkisar dari 9,79-86,46\% (tabel 5.). Nilai INP tertinggi tingkat semai di temukan pada jenis Neprolephis sp. $\mathrm{INP}=86,46 \%$, lalu jenis Hevea brasiliensis $\mathrm{INP}=$ $38,75 \%$. Nilai INP untuk jenis Cyperus sp.,dan Dicranopteris linearis sebesar 12,92\%. Dillenia sp., Nephelium lappaceum, Pandanus tectorius, Elaeis guinensis dan Melastoma candidum memiliki nilai INP yang sama, sebesar 9,79\% (Tabel 5.).

Tabel 5. Komposisi Vegetasi Tingkat Semai

\begin{tabular}{lllllll}
\hline Jenis & N & K & KR (\%) & F & FR (\%) & INP (\%) \\
\hline Dillenia sp. & 1 & 500.00 & 3.13 & 0.20 & 6.67 & 9.79 \\
Neprolephis sp. & 17 & 8500.00 & 53.13 & 1.00 & 33.33 & 86.46 \\
Hevea brasiliensis & 6 & 3000.00 & 18.75 & 0.60 & 20.00 & 38.75 \\
Nephelium lappaceum & 1 & 500.00 & 3.13 & 0.20 & 6.67 & 9.79 \\
Cyperus sp. & 2 & 1000.00 & 6.25 & 0.20 & 6.67 & 12.92 \\
Pandanus tectorius & 1 & 500.00 & 3.13 & 0.20 & 6.67 & 9.79 \\
Dicranopteris linearis & 2 & 1000.00 & 6.25 & 0.20 & 6.67 & 12.92 \\
Elaeis guinensis & 1 & 500.00 & 3.13 & 0.20 & 6.67 & 9.79 \\
Melastoma candidum & 1 & 500.00 & 3.13 & 0.20 & 6.67 & 9.79 \\
\hline Jumlah & 32 & 16000 & 100 & 3 & 100 & \\
\hline
\end{tabular}

\section{Struktur Vegetasi Riparian Di Kawasan Wisata Gunung Poteng}

Struktur jumlah jenis vegetasi pohon pada hutan riparian di kawasan Gunung Poteng dapat dilihat dari sebaran diameter batang dengan rentang $20-80 \mathrm{~cm}$, menunjukan bahwa untuk ukuran diameter batang
20-30 cm memiliki jumlah jenis tertinggi dengan 10 jenis. Ukuran diameter batang 70-80 $\mathrm{cm}$ hanya terdapat 1 jenis vegetasi. Diameter batang pohon 30$40 \mathrm{~cm}$ ditemukan 7 jenis, sedangkan untuk diameter batang $40-50 \mathrm{~cm}$ ditemukan 4 jenis vegetasi. Jumlah jenis vegetasi untuk diameter batang $60-70 \mathrm{~cm}$ sebanyak 3 jenis (Gambar 4.).

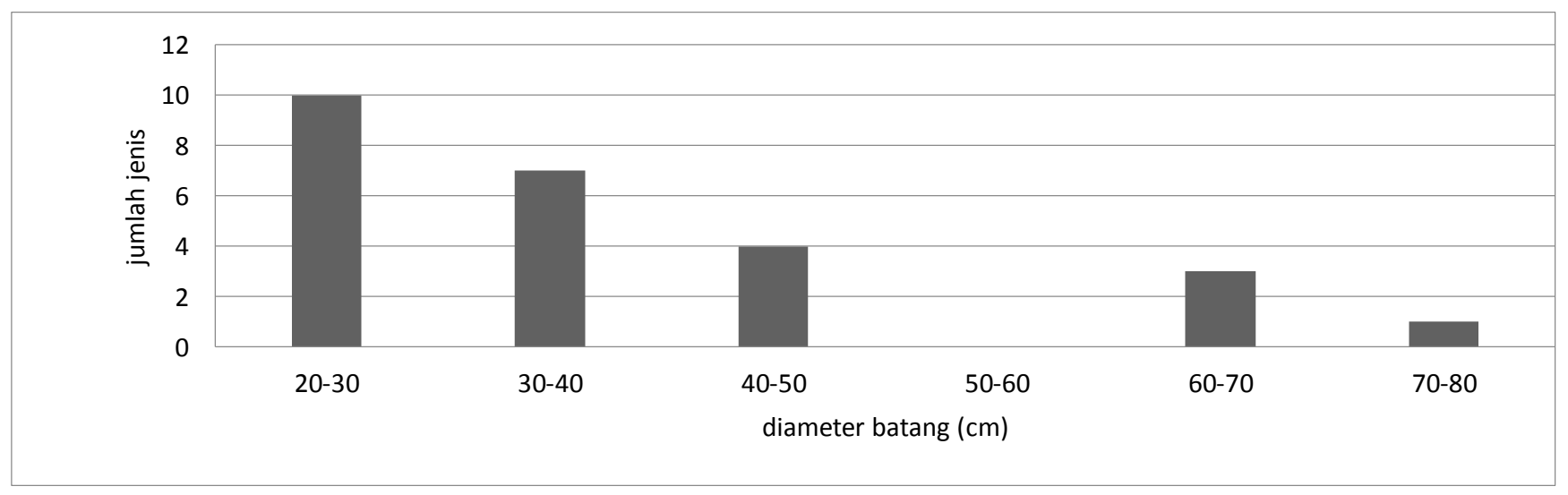

Gambar 4. Grafik Jumlah Jenis Vegetasi Berdasarkan Sebaran Diameter Batang Pada Tingkat Pohon 
Berdasarkan hasil perhitungan (Tabel 6.), didapatkan nilai indeks kemerataan (E') tingkat semai sebesar 0,69997 , tingkat pancang sebesar 0,774397 , tingkat tiang sebesar 0,863121 dan tingkat pohon sebesar 0,7670 . Nilai indeks keanekaragaman (H') tingkat semai sebesar 1,537, tingkat pancang sebesar 1,073, tingkat tiang sebesar 0,598 dan tingkat pohon sebesar 1,374. Nilai indeks dominansi (D) pada tingkat semai sebesar 0,699 , pada tingkat pancang sebesar 0,437, pada tingkat tiang sebesar 0,591 dan pada tingkat pohon sebesar 0,318 .

Tabel 6. Indeks Dominansi, Keanekaragaman Shanon, dan Kemerataan

\begin{tabular}{lllll}
\hline No & Jenis & D & H' $^{\prime}$ & $\mathbf{E}^{\prime}$ \\
\hline 1. & Semai & 0.699971 & 1.537993 & 0.699971 \\
2. & Pancang & 0.4375 & 1.073543 & 0.774397 \\
3. & Tiang & 0.591837 & 0.59827 & 0.863121 \\
4. & Pohon & 0.3184 & 1.374291 & 0.767007 \\
\hline \multicolumn{2}{l}{ Keterangan: D: indeks dominansi, H': indeks keanekaragaman, E': indeks kemerataan }
\end{tabular}

\subsection{Pembahasan}

Berdasarkan hasil penelitian pada petak contoh sebesar 0,03 ha di hutan riparian sekitar kawasan Gunung Poteng ditemukan komposisi vegetasi riparian terdiri dari 23 spesies, 21 marga dan 19 family (Tabel .1), sedangkan pada riparian Kebun Raya Sambas ditemukan 22 spesies, 18 marga, dan 14 famili pada total luas plot $1 \mathrm{Ha}$ yang ditemukan oleh Andriyani et al (2018). Nursal et al (2013), menemukan 13 spesies dan 9 famili pada total luas plot 0,36 ha di riparian kawasan Hutan Rimbo Provinsi Riau. Dari perbandingan dengan beberapa penelitian sebelumya tentang riparian, komposisi vegetasi riparian di kawasan Gunung Poteng memiliki jumlah spesies, marga dan family lebih banyak dari kedua penelitian sebelumnya,meskipun dengan luas total plot yang lebih kecil. Sedangkan untuk family paling mendominasi pada Kebun Raya Sambas yang ditemukan oleh Andriyani et al (2018) adalah family Malvaceae salah satu jenis yang banyak di temukan diantaranya adalah Hibiscus tiliacaeus (waru),berkombinasi dengan Dillenia borneensis (simpur) dari family Dilleniaceae. Pada kawasan Hutan Rimbo Provinsi Riau, Nursal et al (2013) menemukan family Euphorbiaceae pada hampir semua plot pengamatan, jenis vegetasi yang mendominasi yang ditemukan Hevea brasiliensis dan Baccaurea monthleyana.

Keanekaragaman jenis vegetasi menunjukan bahwa hutan riparian di kawasan gunung Poteng masih terjaga dengan baik. Adapun dari jenis-jenis vegetasi yang ditemukan beberapa memiliki kesamaan jenis antara vegetasi tingkat semai, pancang, tiang dan pohon. Berdasarkan tingkat pertumbuhan ditemukan 9 jenis tingkat semai dengan jumlah individu 32, 4 jenis tingkat pancang dengan jumlah individu 8,2 jenis tingkat tiang dengan jumlah individu 7,dan 11 jenis tingkat pohon dengan jumlah individu 25 .

Jenis vegetasi riparian terbanyak tingkat semai adalah Gelichenia sp. sebanyak 17 individu, sedangkan jenis vegetasi riparian paling sedikit ditemukan pada Dillenia sp., Nephelium lappaceum, Pandanus tectorius, Elaeis guineensis Jacq., dan Melastoma candidum masing-masing berjumlah 1 individu. Jenis vegetasi tingkat pancang terbanyak adalah Hevea brasiliensis sebanyak 5 individu, jumlah paling sedikit ditemukan pada jenis Durio zibethinus, Arecaceae sp. dan Gnetum gnemon masing-masing berjumlah 1 individu. Vegetasi tingkat tiang dengan individu terbanyak yaitu Hevea brasiliensis sebanyak 5 individu, sedangkan Alstonia sp. berjumlah 2 individu. Jumlah pohon pada vegetasi riparian terbanyak ditemukan pada jenis Hevea brasiliensis sebanyak 12, untuk tingkat pohon paling sedikit ditemukan pada jenis Mallotus paniculatus, Leucaena leucocephala dan Aquilaria malaccensis dengan jumlah masing-masing 1 individu.

Jika pada hutan alam umumnya, jumlah vegetasi tingkat semai cenderung mendominasi dan memiliki jumlah yang lebih banyak dibandingkan tingkatan lainnya, sehingga hutan dapat dikatakan dalam kondisi normal (Sidiyasa,2009), sama halnya seperti pada riparian kawasan gunung Poteng dimana jumlah paling banyak vegetasi ditemukan pada tingkat semai dengan total 32 individu. Hal ini 
menunjukan bahwa hutan riparian kawasan wisata gunung Poteng masih alami yang sedikit aktivitas manusia. Kawasan wisata gunung Poteng dengan riparian yang masih primer juga masuk kedalam hutan Cagar Alam Pasi. Berdasarkan data penelitian ini, terdapat keseimbangan komposisi hutan alam pada riparian kawasan wisata gunung Poteng dengan komposisi hutan pada umumya.

Kerapatan merupakan jumlah kekuatan suatu jenis tumbuhan dalam suatu komunitas dan menunjukan jumlah tumbuhan per unit area. Kerapatan pohon tertinggi di temukan pada jenis Hevea brasiliensis dengan kepadatan 60 individu/ha $(\mathrm{KR}=48 \%)$, kerapatan tiang tertinggi ditemukan pada jenis Hevea brasiliensis dengan kepadatan 100 individu/ha $(\mathrm{KR}=71,43 \%)$, kerapatan tiang tertinggi di temukan pada jenis Hevea brasiliensis dengan kepadatan 400 individu/ha $(\mathrm{KR}=71,43 \%)$, kerapatan tingkat semai tertinggi di temukan pada jenis Neprolephis sp. dengan kerapatan 8500 individu/ha $(\mathrm{KR}=53,13 \%)$. Tingkat pohon, tiang dan pancang kerapatan jenis Hevea brasiliensis tertinggi dibandingkan jenis lain yang ditemukan pada riparian kawasan gunung Poteng.

Kerapatan yang tinggi untuk jenis Hevea brasiliensis, karena jenis ini mampu hidup bertahan dibawah kanopi yang rapat dan masih bisa menerima cahaya matahari. Menurut Bibiana et al (2015) ketika mencapai tingkat tiang jenis ini sudah memiliki tajuk yang lebar dan perakaran yang kokoh serta panjang, akan memudahkan jenis ini untuk mengalahkan individu lain disekitarnya untuk mendapatkan asupan unsur hara, air dan cahaya. Untuk tingkat semai jenis Neprolephis sp. memiliki kerapatan lebuh tinggi dibandingkan jenis lainnya, hal ini disebabkan jenis Neprolephis sp. ini penyebaran sporanya terbawa oleh angin ketika matang atau dibawa oleh binatang seperti burung.

Tingkat heterogenitas jenis vegetasi dapat dilihat dari nilai frekuensi relatifnya. Frekuensi relatif tertinggi tingkat semai ditemukan pada jenis Neprolephis sp. $(\mathrm{FR}=33.33 \%)$. Tingkat pancang tertinggi di temukan pada jenis Hevea brasiliensis dengan $\mathrm{FR}=71,43 \%$. Fekuensi relatif tingkat tiang tertinggi di temukan pada jenis Hevea brasiliensis dengan FR $=60 \%$, dan Frekuensi relatif tertinggi tingkat pohon di temukan pada jenis Hevea brasiliensis $(\mathrm{FR}=33.33 \%)$. Berdasarkan hasil analisis vegetasi riparian di kawasan gunung Poteng, bahwa jenis Hevea brasiliensis ditemukan hampir pada setiap plot pengamatan. Hal ini menunjukan distribusi vegetasi jenis Hevea brasiliensis tersebar merata pada setiap tingkat regenerasi tegakan.

Hidayat (2001), dalam Yunita (2013) menyatakan indeks nilai penting (INP) diperlukan untuk mengetahui tingkat penguasaan jenis pohon dalam suatu tegakan. Nilai INP tertinggi tingkat pohon di temukan pada jenis Hevea brasiliensis INP = $119,00 \%$, tingkat tiang tertinggi ditemukan pada jenis Hevea brasiliensis dengan nilai INP = $131,43 \%$, tingkat pancang tertinggi ditemukan pada jenis Hevea brasiliensis dengan $\mathrm{INP}=142,86 \%$, dan nilai INP tertinggi tingkat semai di temukan pada jenis Neprolephis $s p$. INP $=86,46 \%$. Nilai INP jenis Hevea brasiliensis menunjukan tingginya tingkat penguasaan di dalam komunitas dimana jenis tersebut tumbuh.

Struktur vegetasi merupakan penampakan susunan tegakan dasar berdasarkan sebaran diameter, tingkat permudaan pancang, tiang dan pohon, lapisan tajuk dan penyebaran dalam ruang, Kafrawi (2005) dalam Ridlawati (2005). Hasil analisis vegetasi di riparian kawasan wisata Gunung Poteng diperoleh jumlah individu terbesar berturut-turut terdapat pada vegetasi tingkat semai (32), pohon (25), pancang (8), dan tiang (7). Hal ini menunjukan adanya perbedaan struktur dan komposisi vegetasi. Menurut Soerianegara dalam Nurfitri (2005) adanya perbedaan tersebut disebabkan oleh perubahan vegetasi yang terjadi terus-menerus dimana suatu populasi digantikan oleh populasi yang lain, bahkan hutan yang stabil pun selalu terjadi perubahan. Hal ini disebabkan karena adanya jenis yang hilang atau mati dan ada pula jenis baru yang muncul pada area hutan tersebut.

Struktur jumlah jenis vegetasi pohon pada hutan riparian di kawasan gunung Poteng dilihat dari sebaran diameter batang dengan rentang $20-80 \mathrm{~cm}$, menunjukan bahwa untuk ukuran diameter batang 20-30 cm memiliki jumlah jenis tertinggi dengan 10 jenis. Hal ini menunjukan bahwa tingkat permudaan atau regenerasi pada kawasan Gunung Poteng masih sangat baik dan masih alami. Hutan kawasan Gunung Poteng merupakan salah satu hutan hujan tropis. Tegakan hutan hujan tropis didominasi oleh pepohonan yang selalu hijau.. Keanekaragaman spesies dan binatang yang ada di hutan hujan tropis sangat tinggi (Indriyanto, 2005). Ukuran diameter batang 70-80 cm hanya terdapat 1 jenis vegetasi, hal ini menunjukan bahwa agak sulit untuk menemukan pohon berukuran besar di hutan riparian kawasan Gunung Poteng. 
Nilai indeks kemerataan (E') tingkat semai sebesar 0,69997 , tingkat pancang sebesar 0,774397 , tingkat tiang sebesar 0,863121 , dan tingkat pohon sebesar 0,7670. Hasil tersebut menunjukkan bahwa indeks kemerataan (E') sama dengan 0 artinya kemerataan antara spesies rendah, perbedaan kekayaan individu yang dimiliki antar spesies sangat jauh berbeda (Odum, 1993). Nilai indeks keanekaragaman (H') tingkat semai sebesar 1,537, tingkat pancang sebesar 1,073 , tingkat tiang sebesar 0,598 dan tingkat pohon sebesar 1,374 .

Nilai indeks keanekaragaman (H') menunjukan hasil $1<\mathrm{H}^{\prime}>3$ yang berarti memiliki keanekaragaman sedang, pada tingkat tiang memiliki nilai $\mathrm{H}^{\prime}<1$ memiliki keanekaragaman yang rendah (Odum,1993). Nilai indeks dominansi (D) pada tingkat semai sebesar 0,699 , pada tingkat pancang sebesar 0,437, pada tingkat tiang sebesar 0,591 dan pada tingkat pohon sebesar 0,318 . Nilai indeks dominansi (D) tingkat semai lebih besar dibandingkan tingkat pancang, tiang dan pohon, nilai indeks dominansi (D) $\mathrm{D}=0$ menunjukkan bahwa dominansi rendah, artinya tidak terdapat spesies yang mendominansi spesies lain (Odum, 1993).

\section{DAFTAR PUSTAKA}

Andriyani, L. Iswan, D. Hafiz, A. 2018. Struktur

Dan Komposisi Jenis Vegetasi Riparian

Kebun Raya Sambas Kabupaten Sambas

Kalimantan Barat. Fakultas Kehutanan.

UNTAN. Pontianak. Jurnal Hutan Lestari 6

(1): 238-245.

Badan Pusat Statistik (BPS). 2015. Kota Singkawang Dalam Angka. Singkawang: Badan Pusat Statistik (BPS).

Bibiana, A. Burhannudin, Iswan, D. 2015. Sruktur Dan Komposisi Vegetasi Di Areal Petak Ukur Permanen (PUP) PT. Kawedar Wood Industry Kabupaten Kapuas Hulu. Fakultas Kehutanan. UNTAN. Pontianak. Jurnal Hutan Lestari 3 (1): 150-159.

Everard, M, dan Moggridge, H. L. 2012. Rediscovering the Value of Urban Rivers. (kota : penerbit)

Ewusie, J, Yanney.1990. Pengantar Ilmu Ekologi Tropika. Bandung: Institut Teknologi Bandung.
Haslam, M.(2008). The Riverscape and The River. Cambridge: Cambridge University Press.

Indriyanto. 2006. Ekologi Hutan. Jakarta: Bumi Aksara.

Indriyanto, 2005. Ekologi Hutan. Jakarta: Bumi Aksara.

Nurfitri, 2005. Struktur Dan Komposisi Vegetasi Riparian Pada Areal HTI. Finnantara Intiga Unit Mengkiang Kabupaten Sanggau. Skripsi. Fakultas Kehutanan. Universitas Tanjungpura. Pontianak.

Nursal, Suwondo, Irma, N. 2013. Karakteristik Komposisi Dan Stratifikasi Vegetasi Strata Pohon Komunitas Riparian Di Kawasan Hutan Wisata Rimbo Tujuh Danau Kabupaten Kampar Provinsi Riau. Program Studi Pendidikan Biologi. PMIPA FKIP. Universitas Riau. Pekanbaru. Jurnal Biogenesis 9 (2).

Odum, 1993. Fundamentals of Ecology, Saunder Company Philadelphia. London. Toronto.

Ramsar, 2013, Ramsar Convention Manual: a Guide to the Convention on Wetlands (Ramsar, Iran, 1971), 6th ed. Gland. Switzerland: Ramsar Convention Secretariat.

Ridlawati, 2008. Struktur Dan Komposisi Vegetasi Di Kawasan Hutan Lindung Bukit Ketopong Desa Sempalai Kabupaten Sambas. Skripsi. Fakultas Kehutanan. Untan. Pontianak.

Sidiyasa, 2009. Struktur Dan Komposisi Tegakan Serta Keanekaragaman Di Hutan Lindung Sungai Wain. Balikpapan. Kalimantan Timur. Jurnal Penelitian Hutan Dan Konservasi Alam 6 (1): 79-93.

Soerianegara, I dan Indrawan, A. 1988. Ekologi Hutan Indonesia, Departemen Manajemen Hutan Fakultas Kehutanan IPB, Bogor.

Supyan. 2011. Pengembangan Daerah Konservasi Sebagai Tujuan Wisata, Jurnal Mitra Bahari.

Wawan, 2011, Penilaian Potensi Wisata. http://www.penilaianpotensiwisata.html . 
Protobiont (2018) Vol. 7 (3) : 118 -126

Wirakusumah, Sambas. 2003. Dasar-dasar Ekologi, Menopang Pengetahuan Ilmu-Ilmu Lingkungan. Jakarta: Universitas Indonesia (UI-Press).

Yunita, T. M. 2013. Studi Penyebaran Kempas (Koompassia malacensis Maing.) Di Areal IUPHHK PT. Wanasokan Hasilindo Kabupaten Ketapang Kalimantan Barat. Skripsi. Fakultas Kehutanan. Universitas Tanjungpura. Pontianak. 